Original Research Paper

\title{
Koswer Multimedia Interaktif Berasaskan Web Bagi Tajuk 'Discovering Computer' Berkonsepkan Strategi Pembelajaran Kendiri
}

\author{
Noralia Akilah Salman ${ }^{1}$, Roznim Mohamad Rasli ${ }^{2}$ \\ ${ }^{1}$ Program of Software Engineering, Department of Computing. Faculty of Art, \\ Computing \& Creative Industry. Universiti Pendidikan Sultan Idris. Tanjong Malim, \\ Malaysia. \\ ${ }^{2}$ Department of Computing. Faculty of Art, Computing \& Creative Industry. Universiti \\ Pendidikan Sultan Idris. Tanjong Malim, Malaysia.
}

Article History
Received:
14.11.2021
Revised:
17.12 .2021
Accepted:
23.12 .2021
*Corresponding Author:
Roznim Mohamad Rasli
Email:
roznim@fskik.upsi.edu.my

This is an open access article, licensed under: $\mathrm{CC}-\mathrm{BY}-\mathrm{SA}$
Abstrak: Teknologi multimedia interaktif telah menyumbang kepada proses pengajaran dan pembelajaran yang lebih efektif khususnya dalam penggunaan perisian instruksional koswer. Tujuan kajian ini adalah untuk membangunkan koswer multimedia interaktif bagi pelajar universiti untuk mempelajari dengan lebih mendalam berkenaan komputer yang bertajuk Discovering Computer "ICDC". Koswer ini dibangunkan dengan menggunakan metodologi ADDIE yang terdiri daripada modul pelajar, video pembelajaran dan koleksi latihan. Pengujian kebolehgunaan meliputi reka bentuk antara muka dan kebolehfungsian dijalankan dengan menggunakan kaedah tinjauan kuantitatif yang melibatkan seramai 33 orang sampel. Sasaran utama koswer ini ialah pelajar universiti yang berumur di antara 18 tahun ke 25 tahun sahaja. Dapatan menunjukkan bahawa kandungan pembelajaran di dalam koswer ini adalah lebih menarik dan interatif berbanding pembelajaran menggunakan teknik pengajaran tradisional iaitu berasaskan buku. Selain itu, pengguna koswer ini dapat meningkatkan mutu dan prestasi pengajaran dan pembelajaran (bahan bantu mengajar) dan juga meningkatkan pengalaman dan motivasi pelajar.

Kata Kunci: Bahan Bantu Mengajar, Koswer Multimedia Interaktif, Pengajaran dan Pembelajaran Komputer, Strategi Pembelajaran Kendiri.

MYSIMBA: Interactive Multimedia Learning Courseware for Grade 6 Students' Idioms Learning

Abstract: Interactive multimedia technology has contributed to a more effective teaching and learning process, especially in the use of instructional software. The purpose of this study is to develop an interactive multimedia courseware for university students to learn more about computer entitle Discovering Computer "ICDC". This courseware is developed by using the ADDIE methodology comprises of student modules, learning videos and a collection of exercises. Software Usability testing consist of interface design and functionality were evaluated using a quantitative survey method that involving 33 samples respondents by student in different categories. The main target of this study is university student's aged between 18 and 25 years old. Findings indicate that the learning content in this book is more interesting and interactive than learning using traditional teaching technique, book based learning. In addition, this courseware can enhance the quality and performance of teaching and learning (teaching aids) and also improve student's experience and motivation.

Keywords: Computer Teaching and Learning, Interactive Multimedia Courseware, Self-Paced Learning Strategies, Teaching Aids. 


\section{Pendahuluan}

Pendidikan Teknologi Maklumat dan Komunikasi (ICT) adalah satu program yang memberi tumpuan kepada teori umum dan amalan pengajaran dan pembelajaran (PnP) yang melibatkan pengoplikasian teknologi yang di dasari oleh prinsip dasar psikologi pendidikan. Prinsip dasar psikologi pendidikan adalah termasuklah seni mengajar, perancangan dan pentadbiran berkaitan pendidikan, isu keselamatan dan kesihatan sekolah serta asas pendidikan sosial. Di dalam bidang pendidikan, kebanyakan ahli akademik seharusnya mempunyai beberapa perancangan untuk mengajar para pelajar menggunakan teknologi. Pendidikan juga boleh disampaikan kepada pelajar melalui penggunaan komputer untuk membolehkan pelajar selesa menggunakan teknologi berbanding buku.

Selain itu, pendidikan ICT juga menjadi tunjang kepada interaksi dua hala di dalam proses PnP. Melalui penggunaan teknologi, ahli akademik dapat menggantikan papan tulis dengan papan digital interaktif secara tidak langsung pada para pelajar dan akan didedahkan dengan penggunaan komputer riba (laptop) atau peranti lain untuk belajar di kelas. Selain itu, pendidikan ICT juga menggalakkan pembelajaran kendiri dimana-mana dan digunakan bila-bila masa sahaja. Justeru, pengaplikasian teknologi dan strategi pembelajaran kendiri menjurus kepada kemahiran berfikir aras tinggi serta menjana pemikiran yang kritis, kreatif dan inovatif. Ini akan melahirkan modal insan yang lebih bersedia untuk menghadapi perubahan drastik teknologi khususnya persekitaran pendidikan 4.0 dan revolusi industri 4.0. Pembentukan modal insan secara asasnya bermula daripada awal pendedahan sehinggalah ke peringkat universiti. Penggunaan teknologi di universiti adalah lebih meluas dan diimplementasikan ke dalam pelbagai bidang dan subjek. Koswer multimedia interaktif adalah satu bahan bantu mengajar (BBM) yang pernah dan/atau sedang digunakan adalah lebih menarik iaitu kerana mempunyai kombinasi teks, audio dan video yang menarik, animasi, gambar bersifat interaktif dan mudah diikuti. Koswer multimedia interaktif adalah pakej koswer untuk menambah atau menggan- tikan pembelajaran tradisional koswer.

Di zaman teknologi yang serba canggih kini, pelajar universiti turut didedahkan dengan pelbagai kaedah dan strategi pembelajaran bagi me- lahirkan modal insan kelas pertama. Sebelum ini, terdapat dua jenis persekitaran pembelajaran pendidikan tradisional. Pertama, persekitaran pengajaran tradisional yang masih banyak digunakan di sekolah. Lazimnya, melibatkan cara mengajar orang zaman dahulu melalui pembacaan, sebagai contoh para pelajar akan duduk secara diam, dan bergilir-gilir untuk membaca pelajaran itu, sehingga setiap orang dipanggil. Guru akan mendengar pembacaan setiap peringkat, dan mereka hanya perlu untuk belajar dan menghafal tugasan. Pada akhir modul, ujian bertulis atau peperiksaan lisan akan dijalankan dimana proses ini dikenali sebagai sebagai kajian tugasan bacaan [1]. Keduanya, persekitaran pengajaran berasaskan ganjaran. Di mana kaedah pengajaran tradisional diajar dengan memastikan pelajar diberi ganjaran untuk usaha mereka, menggunakan waktu kelas dengan cekap dan melaksanakan peraturan yang jelas untuk menguruskan tingkah laku pelajar. Para guru memberikan pengetahuan tentang tingkah laku yang harus dipraktikkan dalam pembelajaran [1].

Namun begitu, proses PnP tetap berlangsung di dalam kelas yaag bersifat statik dan sehala sedangkan setiap pelajar itu mempunyai tahap in- telektual dan tingkah laku yang berbeza-beza. Bagi mengatasi permasalahan ini, pendidikan progresif telah dicadangkan dan diperkenalkan. Dida- lam pendidikan progresif ini, ia dapat memberikan perhatian yang lebih kepada keperluan setiap pelajar kerana tidak semua pelajar berada di tahap pemahaman yang sama [1]. Justeru, pembaharuan pendidikan dapat dipelajari dari sudut yang berbeza melalui aplikasi yang tidak ber- sesuaian.

Selain itu, kaedah pengajaran moden seperti penggunaan koswer di dalam proses $\mathrm{PnP}$ adalah lebih efektif melalui teknik menyoal, menjelaskan, demonstrasi dan kolaborasi berbanding pendekatan tradisional yang statik dan bersifat sehala. Di antara kelebihan yang terdapat di dalam koswer adalah penyediaan navigasi mudah alih untuk pelajar berinteraksi bersama dan menyediakan pembelajaran yang lebih efisien dan menarik untuk setiap pelajar. Pelajar tidak perlu menggunakan buku tebal atau buku rujukan lain untuk memahami PnP kerana isi kandungan, latihan pengukuhan, permainan dan koleksi video telah tersedia dirangkum dalamnya.

Kesepaduan di dalam koswer multimedia interaktif ini juga amat bersesuaian untuk diterapkan di dalam PnP berkaitan komputer. Ini adalah kerana, proses PnP menggunakan pelbagai platform yang perlu dicapai satu per satu yang memakan masa PnP. Selain itu, kandungan berkaitan komputer yang agak kabur dan kompleks menyukarkan pemahaman pelajar di dalam topik Discovering Computer. Justeru, kajian penyelidikan ini bertujuan membangunkan koswer multimedia interaktif untuk topik Discovering Computer yang memfokuskan kepada strategi pembelajaran kendiri dengan menggunakan web sebagai technology enables. 


\section{Kajian Literature}

\subsection{Teknologi Multimedia}

Salah satu faedah yang boleh diperoleh dengan menggunakan teknologi multimedia ialah pendidik diberi peluang yang sangat baik untuk menunjukkan dan menggambarkan subjek dengan lebih jelas. Guru teknologi multimedia juga boleh menyediakan bahan pengajaran untuk pelajar serta dapat mengoptimumkan diri mereka dalam pembelajaran koswer ICDC ini. Tambahan pula, teknologi multimedia menyediakan kaedah alternatif yang terbaik untuk pengajaran dan pembelajaran yang sangat berguna untuk pengguna dan membawa kepada kejayaan pembangunan psikomotor dan pengukuhan pemprosesan visual pengguna [2].

Dengan manfaat yang diperolehi daripada penggunaan teknologi multimedia, pereka perlu mereka bentuk dan membina koswer multimedia interaktif yang lebih efektif serta dapat meningkatkan kualiti pengajaran. Pengajaran koswer multimedia interaktif yang terbaik perlu mempunyai kandungan buku yang inovatif dan mempunyai unsur-unsur kreatif. Dengan reka bentuk yang menarik boleh membawa pelajar untuk menvisualkan konsep yang sukar dan semula jadi dinamik, menggalakan pembelajaran aktif, daya menyelesaikan masalah dan pemikiran kritikal melalui simulasi interaktif dan persekitaran maya, berinteraksi dengan kandungan dan kuiz secara kendiri dan mengakses kandungan pada bila-bila masa dan di mana- mana sahaja.

Pembelajaran kendiri akan membolehkan pelajar untuk memilih secara sukarela aktiviti pembelajaran mereka dan menetapkan matlamat pembelajaran mereka sendiri. Koswer multimedia interaktif adalah pilihan untuk memenuhi keperluan pembelajaran dalam konteks yang berbeza bagi pensyarah dan pelajar [3]. Ini turut disokong oleh kajian penyelidikan yang dijalankan oleh [4] yang menyatakan bahawa simulasi, model dan bahan kajian media seperti grafik, video, audio animasi dan animasi perlu digabung secara tersusun untuk memudahkan pembelajaran pengetahuan baru dengan lebih menarik dan berkesan. Selain itu, ia juga akan lebih memberikan kefahaman untuk mempelajari strategi pembelajaran.

\subsection{Teknologi Multimedia Interaktif}

Multimedia merujuk kepada gabungan dua atau lebih media maklumat yang berlainan dalam koswer komputer [5] [6]. Media ini terdiri daripada teks, imej, audio, video, animasi dan interaktiviti. Secara teorinya, multimedia adalah gabungan teks, gambar, seni grafik, bunyi, animasi, dan elemen yang dimanipulasi secara digital [7] [8]. Dalam konteks ini, teknologi multimedia interaktif dianggap sebagai gabungan teks, grafik, bunyi, animasi, video dan interaktiviti yang disampaikan oleh beberapa bentuk media di dalam komputer. Penggunaan yang terkawal dan tersusun di antara bentuk media dapat menjadikan multimedia itu sebagai multimedia interaktif [8].

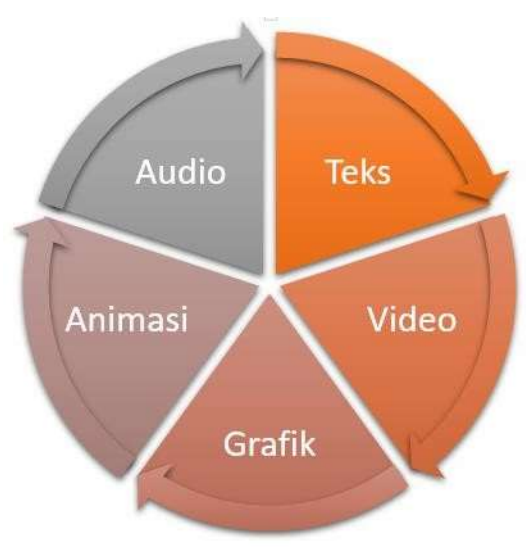

\section{Rajah 1. Komponen Multimedia}

Multimedia yang tidak interaktif, mungkin hanya membolehkan pelajar untuk menekan masuk ke ruangan skrin dan paparan yang ditayangkan hanya secara sahaja. Tutorial akan menjadi interaktif jika pelajar diberi kebebasan untuk mencuba, contohnya jika jawapan mereka kepada soalan menentukan skrin mana yang akan datang seterusnya [7]. Pengaplikasian multimedia dan konsep interaktif ini boleh 
bermula dari awal (scratch) menggunakan aplikasi perisian sedia ada. Mungkin terdapat koswer yang sudah tersedia untuk pengguna menggunakannya atau koswer yang tersedia boleh diubah oleh pengguna mengikut minat grafiknya. Proses mengubahsuai program sedia ada atau menggunakan tutorial shell akan mengurangkan usaha yang diperlukan, dan mungkin menghasilkan antara muka pengguna yang berkualiti untuk diuji dan dinilai oleh pelajar [8].

\subsection{Pengajaran dan Pembelajaran}

Pengajaran dan Pembelajaran (PnP) merujuk kepada proses pengajaran oleh guru bagi membolehkan pembelajaran berlaku dalam kalangan pelajar. Proses $\mathrm{PnP}$ ini boleh berlaku di dalam mahupun di luar kelas, dalam talian atau di luar talian, sehala atau dua hala, tradisional atau konvensional. Penentuan pemilihan ini lazimnya ditentukan berdasarkan kepada alatan pembelajaran yang digunakan, teori pembelajaran, strategi pembelajaran dan analisis pembelajaran.

\subsubsection{Alatan Pembelajaran}

Prastowo [9] menyatakan bahawa alat pengajaran dan pembelajaran adalah bahan yang direka secara sistematik sama ada bertulis atau tidak bertulis yang membolehkan pelajar belajar. Alatan pembelajaran dapat memudahkan pelajar untuk belajar sama ada di dalam atau di luar kelas [10]. Pembelajaran secara dinamik dapat berkembang untuk memenuhi permintaan masyarakat dan sejajar dengan kemajuan teknologi [11]. Namun, perlu dirancang secara kritikal untuk memenuhi keperluan kurikulum dengan mempertimbangkan keperluan pengajar, pelajar, dan konteksnya. Perancangan ini melihat kepada kepelbagaian jenis alatan seperti bahan visual, percetakan dan bukan percetakan, serta objek sebenar.

Pengaplikasian pembelajaran berasaskan komputer telah mengoptimumkan minat dan perolehan pengetahuan. Justeru, penggunaan komputer dalam PnP telah banyak dikaji dan digunakan. Pelbagai alatan pembelajaran telah dibangunkan, termasuklah untuk orang kelainan upaya. Kandungan pembelajaran bagi orang cacat penglihatan telah dibangunkan oleh [12] dengan menggabungkan teori keperlbagaian kepintaran Multiple Intelligence Theory, di mana ia dipengaruhi oleh model SECI.

\subsubsection{Teori Pembelajaran}

Ertmer \& Newby [13], menjelaskan bahawa terdapat kepentingan untuk menghubungkan strategi pengajaran kepada teori pembelajaran. Mereka menunjukkan bahawa teori pembelajaran dianggap sebagai sumber untuk mengesahkan pengajaran serta pemilihan kursus asas. Teori pembelajaran menerangkan tentang hubungan di antara strategi, konteks, dan ciri-ciri pelajar untuk integrasi yang lebih baik dan yang paling utama, teori pembelajaran memberi ramalan tentang keberkesanan strategi pengajaran yang diimplementasi.

Kelakuan, kognitif, dan konstruktif adalah tiga teori pembelajaran utama. Ciri-ciri umum teori ini ditunjukkan dalam Jadual 1. Tiga teori adalah berbeza dengan pembelajaran yang ditakrifkan, kemudiannya membawa kepada peranan yang berbeza bagi pelajar, dan menetapkan kaedah pengajaran serta menggunakan strategi penilaian yang berbeza [14].

Teori pembelajaran yang digunakan dalam koswer ini ialah teori kognitif. Teori kognitif dalam pembelajaran bergantung kepada bagaimana seseorang individu itu berfikir dan mengamal sesuatu, kemuadian maklumat itu diproses dalam fikiran dan pengalaman itu dianjurkan dan dibezakan dalam pemikiran dan persepsi.

Perubahan kognitif dikaitkan dengan perubahan kualiti pemikiran seperti peningkatan pengetahuan dan keupayaan. Ramai ahli psikologi kognitif bersetuju bahawa perubahan yang berlaku dalam diri pelajar adalah disebabkan oleh interaksi pelajar dengan persekitaran dan situasi pembelajaran yang dialami. Sebagai contoh, dalam koswer ini, pelajar mempunyai pengetahuan asas tentang topik tetapi koswer ini lebih menekankan soalan yang terkandung dalam pelajaran. Soalan-soalan diberikan berdasarkan soalan kemahiran berfikir aras tinggi (KBAT). Oleh itu, pelajar dapat meningkatkan pengetahuan di dalam pembelajaran kendiri menggunakan koswer koswer ICDC ini.

\subsubsection{Analisis Pembelajaran}

Sebelum membangunkan koswer berasaskan permainan, analisis untuk pelajar perlu dibuat bagi mengetahui ciri-ciri umum pengguna sasaran. Koswer yang dibangunkan lebih fokus kepada pelajar universiti yang berumur 18 tahun dan ke atas. Selain itu, pereka perlu mengetahui tahap pengetahuan pelajar terlebih dahulu. Pelajar sepatutnya mengetahui topik atau kandungan subjek dalam koswer ini kerana buku teksnya sudah ada. Pelajar perlu memahami topik yang diajar oleh guru supaya pelajar tidak mempunyai masalah dengan soalan dan latihan daripada koswer ini. 
Jadual 1. Tiga Jenis Teori Pembelajaran Utama [14]

\begin{tabular}{|c|c|c|c|}
\hline Ciri-ciri & Kelakuan & Kognitif & Konstruktif \\
\hline $\begin{array}{l}\text { Definisi } \\
\text { Pembelajaran }\end{array}$ & $\begin{array}{l}\text { Pembelajaran adalah } \\
\text { pemerolehan tingkah } \\
\text { lakubaru }\end{array}$ & $\begin{array}{l}\text { Pembelajaran } \\
\text { melibatkan pemerolehan } \\
\text { dan penyusunansemula } \\
\text { struktur kognitif }\end{array}$ & $\begin{array}{l}\text { Pembelajaran adalah } \\
\text { mencarimakna }\end{array}$ \\
\hline Peranan Pelajar & $\begin{array}{l}\text { Peserta pasif dalam proses } \\
\text { pembelajaran }\end{array}$ & $\begin{array}{l}\text { Peserta aktif dalam proses } \\
\text { pembelajaran }\end{array}$ & $\begin{array}{l}\text { Peserta aktif dalam } \\
\text { prosespembelajaran }\end{array}$ \\
\hline $\begin{array}{l}\text { Implikasi Strategi } \\
\text { Utama }\end{array}$ & $\begin{array}{l}\text { Memudahkan mengetahui } \\
\text { apa: } \\
\text { - Arahan } \\
\text { berdasarkan } \\
\text { objektif } \\
\text { - Pendidikan } \\
\text { berasaskan } \\
\text { kecekapan } \\
\text { - Kemahiran dan latihan } \\
\text { kemahiran }\end{array}$ & $\begin{array}{l}\text { Memudahkan } \\
\text { mengetahui bagaimana } \\
\text { - Peta konsep } \\
\text { - Pemikiran reflektif }\end{array}$ & $\begin{array}{l}\text { Refleksi dalam tindakan } \\
\text { - Persekitaran } \\
\text { pembelajaran } \\
\text { berasaskan kes yang } \\
\text { tulen } \\
\text { - Amalan reflektif } \\
\text { - Pembinaan } \\
\text { pengetahuan secara } \\
\text { kolaboratif }\end{array}$ \\
\hline $\begin{array}{l}\text { Contoh Kaedah } \\
\text { Pengajaran }\end{array}$ & $\begin{array}{l}\text { Kuliah } \\
\text { - Simulasi } \\
\text { - Demonstrasi } \\
\text { - Arahan yang } \\
\text { diprogramkan }\end{array}$ & $\begin{array}{l}\text { - Penyelesaian masalah } \\
\text { - Pemetaan konsep } \\
\text { - Penganjur lanjutan }\end{array}$ & $\begin{array}{l}\text { - } \text { Diari / refleksi } \\
\text { - Pemodelan } \\
\text { peranan } \\
\text { - Pembelajaran } \\
\text { berasaskan ma- salah } \\
\text { - Pembelajaran } \\
\text { kolaboratif }\end{array}$ \\
\hline Strategi Penilaian & $\begin{array}{l}\text { Penilaian rujukan krite- } \\
\text { ria: pelbagai soalan pili- } \\
\text { han dan barangan ingat }\end{array}$ & $\begin{array}{l}\text { Esei, laporan bertulis, } \\
\text { dan kajian }\end{array}$ & $\begin{array}{l}\text { Penghapusan gred dan } \\
\text { ujian piawai; pengredan / } \\
\text { semakan rakan } \\
\text { sebaya }\end{array}$ \\
\hline
\end{tabular}

\subsection{Koswer Multimedia Interaktif}

\subsubsection{Koswer Sedia Ada}

Dalam era globalisasi ini, kandungan pembelajaran perlu digabungkan dengan pelbagai media. Mayer [15] mendefinisikan multimedia sebagai gabungan teks dan gambar. Sementara itu, Ariani \& Haryanto [16] serta Pilli \& Aksu [17] menjelaskan bahawa multimedia digunakan dalam PnP untuk menyampaikan maklumat (pengetahuan, psikomotor dan sikap) dan merangsang pemikiran, perasaan, perhatian dan penyediaan supaya pembelajaran terkawal. Koswer interaktif digabungkan dengan lima jenis media asas ke dalam persekitaran pembelajaran iaitu teks, video, bunyi, grafik, animasi serta interaktiviti. Oleh kerana mod pembelajaran adalah interaktif dan tidak linear, pelajar atau guru boleh memilih koswer ini sebagai strategi pembelajaran yang terbaik.

Menurut Asyhar [18], media pembelajaran dapat memindahkan maklumat daripada pengirim kepada penerima, dengan persekitaran yang kondusif yang menjadikan proses pembelajaran berkesan dan efisien. Selain itu, Musfiqon [19] mendefinisikannya sebagai alat fizikal atau bukan fizikal yang sengaja digunakan sebagai mediator antara guru dan pelajar dalam memastikan kandungan pembelajaran difahami dengan baik.

Terdapat tiga strategi yang berbeza yang boleh diterapkan iaitu Multimedia-assisted Mastery Learning (MML), Multimedia-assisted Cooperative Learning (MCL) dan Multimedia-assisted Cooperative Mastery Learning (MCML). MML menggunakan pendekatan pembelajaran kendiri manakala MCL dan MCML melibatkan pembelajaran dalam kumpulan. Pemilihan strategi adalah bergantung kepada media pembelajaran yang digunakan.

\subsubsection{Interaktif Koswer}

Setiap orang mempunyai pandangan yang berbeza terhadap tahap interaktiviti. Setiap pandangan dan pendapat mempunyai sedikit perbezaan dan diukur berdasarkan makna yang sama. Menurut Crawford 
[20], interaktiviti boleh digunakan secara dalam talian atau luar talian untuk permainan, melayari web, pembelajaran atau aktiviti yang berlainan. Crawford [20] juga turut mencadangkan lima tahap interaktiviti, iaitu pemerhatian, penyertaan, tindakan, agensi, dan pemilikan (rujuk Jadual 2).

Jadual 2. Lima Tahap Interaktiviti [20]

\begin{tabular}{|c|c|}
\hline Tahap & Penerangan \\
\hline $\begin{array}{l}\text { Tahap 1: } \\
\text { Pemerhatian }\end{array}$ & $\begin{array}{l}\text { Pemerhatian adalah tahap interaksi yang paling rendah iaitu peringkat } 1 . \\
\text { Pengamatan memerlukan input yang mudah dari pengguna. Tahap ini } \\
\text { tidak mempunyai komponen "berfikir" dan "mendengar" seperti } \\
\text { televisyen dan dewan kuliah yang besar. }\end{array}$ \\
\hline $\begin{array}{l}\text { Tahap 2: } \\
\text { Peserta }\end{array}$ & $\begin{array}{l}\text { Penyertaan seperti namanya memerlukan beberapa, walaupun sedikit, } \\
\text { penglibatan dari pengguna. Sebagai contoh, melayari web, bilik darjah } \\
\text { kecil, buku, dan e-pembelajaran. Para pengguna lebih terlibat dalam arah } \\
\text { dan kandungan cerita daripada di Tahap } 1 \text {. }\end{array}$ \\
\hline $\begin{array}{l}\text { Tahap 3: } \\
\text { Tindakan }\end{array}$ & $\begin{array}{l}\text { Aksi, adalah tahap } 3 \text { tahap interaktiviti, ia memerlukan pengguna"input } \\
\text { penting. Tahap ini melibatkan "mendengar", "berfikir", dan"bercakap". } \\
\text { Contoh-contoh tahap ini adalah cawangan, kedudukan, dan sortasi. }\end{array}$ \\
\hline $\begin{array}{l}\text { Tahap 4: } \\
\text { Agensi }\end{array}$ & $\begin{array}{l}\text { Tahap keempat ialah Agensi, yang merujuk kepada tindakan dan hasilnya. } \\
\text { Tahap ini adalah sama dengan tahap sebelumnya yang juga memerlukan } \\
\text { pengguna "input penting tetapi adalah pautan langsung kepada tindakan } \\
\text { dan hasil dunia sebenar. }\end{array}$ \\
\hline $\begin{array}{l}\text { Tahap 5: } \\
\text { Pemilikan }\end{array}$ & $\begin{array}{l}\text { Pemilikan adalah tahap terakhir dalam tahap interaktiviti. Ia adalah di luar } \\
\text { pembelajaran di mana pengguna mengintegrasikan kandungan ke dalam } \\
\text { kehidupan seharian. Di peringkat ini, pengguna mengetahui } \\
\text { kandungannya dengan baik untuk memulakan kitaran dan mengajarnya } \\
\text { kepada generasi akan datang. }\end{array}$ \\
\hline
\end{tabular}

Cramford [20], telah menggariskan empat tahap masa pembangunan dan tahap kerumitan interaktiviti yang merupakan interaksi pasif, terhad, interaksi komplek, dan interaksi masa nyata.

Jadual 3. Masa Pembangunan dan Tahap Kerumitan Interaktiviti [20]

\begin{tabular}{|c|c|}
\hline Tahap & $\begin{array}{l}\text { Penerangan } \\
\end{array}$ \\
\hline $\begin{array}{l}\text { Tahap 1: } \\
\text { Pasif }\end{array}$ & $\begin{array}{l}\text { Pengguna hanya menerima maklumat tersebut. Sebagai contoh, } \\
\text { pengguna membaca teks pada skrin, melihat carta, grafik, ilustrasi, dan } \\
\text { menggunakanbutang navigasi untuk mengemudi program atau sistem. }\end{array}$ \\
\hline $\begin{array}{l}\text { Tahap 2: } \\
\text { Interaksi } \\
\text { Terbatas }\end{array}$ & $\begin{array}{l}\text { Tahap ini memerlukan tanggapan mudah dari pengguna. Sebagai contoh, } \\
\text { pelbagai pilihan berasaskan senario, padanan lajur yang berkaitan dengan } \\
\text { persembahan grafik dan teks. Biasanya ia memerlukan teks atau audio } \\
\text { untuk memberikan jawapan }\end{array}$ \\
\hline $\begin{array}{l}\text { Tahap 3: } \\
\text { Interaksi } \\
\text { Kompleks }\end{array}$ & $\begin{array}{l}\text { Tahap yang terdiri daripada simulasi aplikasi yang kompleks yang } \\
\text { memerlukan pengguna memasukkan data ke dalam koswer. Ia adalah } \\
\text { cawangan berasaskan senario bahawa pengguna mengalami tindak balas } \\
\text { yang salah dan membuat keputusan mereka sendiri. }\end{array}$ \\
\hline $\begin{array}{l}\text { Tahap 4: } \\
\text { Interaksi Masa } \\
\text { Nyata }\end{array}$ & $\begin{array}{l}\text { Pengguna yang terlibat secara langsung dalam isyarat dan tanggapan } \\
\text { kompleks seperti kehidupan. Sebagai contoh, simulasi 3D kehidupan } \\
\text { sebenar, penggunaan teknologi permainan, dan pembelajaran dan } \\
\text { penilaian masa nyata. }\end{array}$ \\
\hline
\end{tabular}

\subsection{Pembangunan Aplikasi Berasaskan Web}

Aplikasi berasaskan web adalah aplikasi yang berada dalam pelayar (server) dan disampaikan menggunakan rangkaian internet melalui antara muka program. 
Jadual 4. Perbandingan: Aplikasi Native, Hibrid dan Mudah Alih [21] [22] [23]

\begin{tabular}{|c|c|c|c|}
\hline \multirow{2}{*}{$\begin{array}{r}\text { Native } \\
\text { Penjelasan }\end{array}$} & Native & Hibrid & Mudah Alih \\
\hline & $\begin{array}{l}\text { - Native adalah aplikasi } \\
\text { menjangkau capaian } \\
\text { kerangka kerja mudah } \\
\text { alih. } \\
\text { Memandangkan } \\
\text { aplikasi dihasilkan di } \\
\text { dalam sistem biologi, } \\
\text { aplikasi ini juga } \\
\text { mempunyai banyak } \\
\text { kelebihan dan boleh } \\
\text { membuat individu } \\
\text { tertarik untuk } \\
\text { menggunakannya. } \\
\text { Pelanggan mudah } \\
\text { untuk memikirkan } \\
\text { cara menjelajahi } \\
\text { aplikasi. an lampau } \\
\text { Aplikasi yang lang } \\
\text { mempunyai } \\
\text { kedudukan yang } \\
\text { sangat menggalakkan } \\
\text { tetapi sukar untuk } \\
\text { dicapai walaupun asas } \\
\text { pelaksa- naan cepat. } \\
\text { Aplikasi Native boleh } \\
\text { digunakan sama ada } \\
\text { pada pautan Android } \\
\text { atau iOS. }\end{array}$ & $\begin{array}{l}\text { - Aplikasi hybrid adalah } \\
\text { di pusat, laman web } \\
\text { digumpal ke } \\
\text { pembungkus tempatan } \\
\text { - Program web tidak } \\
\text { perlu membina ap- } \\
\text { likasi yang ber beza } \\
\text { untuk setiap peringkat. } \\
\text { - Hibrid mempunyai } \\
\text { persamaan dengan } \\
\text { aplikasi Native tetapi } \\
\text { mempunyai kawalan } \\
\text { untuk me- nyokong } \\
\text { laman web organisasi. } \\
\text { - Aplikasi Hibrid boleh } \\
\text { digunakan pada } \\
\text { Android, iOS dan lain- } \\
\text { lain. }\end{array}$ & $\begin{array}{l}\text { - Aplikasi mudah alih } \\
\text { adalah aplikasi produk } \\
\text { yang berkembang } \\
\text { terutamanya untuk } \\
\text { digunakan pada alat } \\
\text { pendaftaran kecil dan } \\
\text { jauh. } \\
\text { - Contohnya, telefon } \\
\text { bimbit dan tablet } \\
\text { canggih, berbanding } \\
\text { dengan desktop atau } \\
\text { telefon pintar. } \\
\text { - Aplikasi mudah alih } \\
\text { terdiri daripada } \\
\text { permintaan an } \\
\text { keperluan an alat } \\
\text { tambahan antuk } \\
\text { mengeksploitasi apa-apa } \\
\text { kebolehan tertentu. } \\
\text { - Aplikasi mudah alih } \\
\text { kadang kala ikategorikan } \\
\text { mengikut sama ada } \\
\text { aplikasi web, aplikasi } \\
\text { native atau aplikasi } \\
\text { hybrid a mudah } \\
\text { - Setiap aplikasi muar ciri-ciri } \\
\text { alih mempunyai } \\
\text { mereka sendiri. }\end{array}$ \\
\hline $\begin{array}{l}\text { Kemahiran } \\
\text { untuk mencapai } \\
\text { pautan An-droid } \\
\text { dan } i O S\end{array}$ & $\begin{array}{l}\text { Objektif-C, Java, iOS } \\
\text { SDK, Android SDK }\end{array}$ & $\begin{array}{l}\text { CSS, HTML, JavaScript, } \\
\text { Pembangunan Mudah } \\
\text { Alih Rangka Kerja }\end{array}$ & JavaScript, CSS, HTML5 \\
\hline Peruntukan & App Store / Pasaran & App Store / Pasaran & App Store / Pasaran \\
\hline $\begin{array}{l}\text { Kelajuan } \\
\text { Kemajuan } \\
\end{array}$ & Perlahan & Sederhana & Cepat \\
\hline Kos Kemajuan & Tinggi & Sederhana & Rendah \\
\hline $\begin{array}{l}\text { Kos } \\
\text { Penyelenggaraan }\end{array}$ & Tinggi & Sederhana & Rendah \\
\hline $\begin{array}{l}\text { Pelaksanaan } \\
\text { Grafik }\end{array}$ & Tinggi & Sederhana & Sederhana \\
\hline $\begin{array}{l}\text { Pelaksanaan } \\
\text { Aplikasi }\end{array}$ & Cepat & Sederhana & Sederhana \\
\hline
\end{tabular}

Secara asasnya, program komputer peribadi membenarkan pengguna menyerahkan dan memulihkan maklumat atau dari pangkalan data melalui rangkaian internet menggunakan program web yang disukai mereka. Pembanguna dan aplikasi berasaskan web ini kebiasaannya menggunakan bahasa pengaturcara Hypertext Markup Language (HTML) dan Cascading Style Sheets (CSS) untuk menghasilkan antaramuka pengguna dengan perubahan tahap keupayaan dan pencapaian [21].

Pengguna menjangkakan aplikasi web menjadi lebih mudah digunakan, lebih dipercayai, dan lebih selamat untuk digunakan. Oleh kerana kebergantungan terhadap aplikasi berasaskan web telah meningkat secara drastic dari tahun ke tahun, prestasi, kebolehpercayaan, kualiti, kebolehkerjaan telah menjadikan aplikasi web sangat penting. Dan kebanyakan sistem berasaskan web terintegrasi dengan sistem maklumat tradisional yang lain seperti pangkalan data dan sistem pemprosesan transaksi. Beberapa aplikasi yang lebih baru juga dikaitkan dengan aplikasi perkhidmatan web yang memudahkan pertukaran maklumat.

Berdasarkan Jadual 4, aplikasi mudah alih sesuai untuk pembangunan koswer kerana kebanyakan 
ciri seperti kos kemajuan, kos penyelenggaraan dan pelaksanaan grafik adalah rendah berbanding dengan aplikasi hibrid yang mempunyai tahap sederhana dan aplikasi Native yang mempunyai tahap yang tinggi.

\subsection{Perbandingan Metodologi}

Kebanyakan model reka bentuk pengajaran semasa adalah spin-off atau variasi model ADDIE. Model lain termasuk model Dick \& Carey dan Kemp ISD. Satu peningkatan yang diterima umum untuk model ini ialah penggunaan Rapid prototyping. Ini adalah idea untuk menerima maklum balas yang berterusan atau formatif sementara untuk bahan-bahan pengajaran. Model ini dapat menjimatkan masa dan wang kerana pengguna boleh menggunakan koswer dengan percuma. Teori pengajaran juga memainkan peranan penting dalam reka bentuk bahan pengajaran. Teori seperti tingkah laku, konstruktif, pembelajaran sosial dan kognitif membantu membentuk dan menentukan bahan pengajaran.

Model reka bentuk pengajaran menyediakan garis panduan untuk mengatur senario pedagogi yang sesuai untuk mencapai matlamat pengajaran. Reka bentuk pengajaran dapat didefinisikan sebagai amalan mencipta pengalaman pengajaran untuk membantu memudahkan pembelajaran dengan lebih berkesan. Driscoll \& Carliner [24] menyatakan bahawa reka bentuk adalah lebih daripada satu proses. Proses dan hasil yang didapati, merupakan rangka pemikiran [25].

\subsubsection{Model Rapid Prototyping}

Model prototaip pantas adalah prototaip sebelum koswer yang sebenar. Model prototaip pantas mempunyai keupayaan fungsi yang terhad dan prestasi yang tidak cekap berbanding dengan koswer sebenar.

Fungsi "dummy" digunakan untuk membuat prototaip. Selain itu, prototaip pantas adalah cara yang lebih cepat untuk membangunkan program latihan. Fasa reka bentuk dan pembangunan dilakukan pada masa yang sama dan penilaian dilakukan sepanjang proses. Ini adalah mekanisma yang berharga untuk memahami keperluan pelanggan. Prototaip koswer dibina sebelum koswer sebenar mendapat maklum balas daripada pelanggan. Setelah dilaksanakan dan prototaip sekali lagi ditinjau oleh pelanggan untuk sebarang perubahan. Proses diteruskan sehingga model ini diterima oleh pelanggan.

\section{Jadual 5. Kelebihan dan Kekurangan Rapid Prototyping}

\begin{tabular}{|c|c|}
\hline Kelebihan & Kelemahan \\
\hline $\begin{array}{l}\text { Menggalakkan dan memerlukan penyertaan } \\
\text { pelajar aktif dalam proses reka bentuk. }\end{array}$ & $\begin{array}{l}\text { - Kadang-kadang menggalakkan kaedah reka } \\
\text { bentuk tidak formal yang boleh menyebabkan } \\
\text { lebih banyak masalah yangperlu diperbetulkan. }\end{array}$ \\
\hline $\begin{array}{l}\text { - Pelanggan tidak mengetahui keperluan } \\
\text { mereka sehingga mereka melihatnya } \\
\text { dilaksanakan. }\end{array}$ & $\begin{array}{l}\text { - Sebaik sahaja kami mendapat syarat yang } \\
\text { sesuai dari pelanggan selepas menunjukkan } \\
\text { model prototaip, selepas itu, ia tidak boleh } \\
\text { digunakan. Itulah sebabnya, kadangkala kita } \\
\text { merujuk kepada prototaip sebagai prototaip } \\
\text { "Throw-away". }\end{array}$ \\
\hline - Ia mempercepatkan kitaran pembangunan & - Ia adalah proses perlahan \\
\hline $\begin{array}{l}\text { - Kadang-kadang ia membantu untuk } \\
\text { menunjukkan konsep kepada prospektif } \\
\text { pelabur untuk mendapatkan pembiayaan } \\
\text { untuk kajian. }\end{array}$ & $\begin{array}{l}\text { - Terlalu banyak penglibatan pelanggan, tidak } \\
\text { selalu disukai oleh pemaju. }\end{array}$ \\
\hline $\begin{array}{l}\text { - Ia mengurangkan risiko kegagalan, kerana } \\
\text { potensi risiko dapat dikenal pasti awal dan } \\
\text { langkah-langkah mitigasi dapat diambil. }\end{array}$ & $\begin{array}{l}\text { - Pengenalpastian elemen yang tidak berfungsi } \\
\text { adalah sukar untuk didokumentasikan. }\end{array}$ \\
\hline - Mengurangkan kos pembangunan & \\
\hline $\begin{array}{l}\text { Boleh meningkatkan kreativiti melalui } \\
\text { maklum balas pengguna yang lebih cepat }\end{array}$ & \\
\hline $\begin{array}{l}\text { - Ia membolehkan komunikasi yang lebih baik } \\
\text { antara pereka dan pengguna kerana keper- } \\
\text { luan jelas dinyatakan dari awal. Hasilnya } \\
\text { adalah dalam produk yang lebih baik. }\end{array}$ & $\begin{array}{l}\text { - Boleh membawa kepada komitmen yang belum } \\
\text { matang untuk reka bentuk jika tidak diingati } \\
\text { bahawa reka bentuk hanya demonstrasi. }\end{array}$ \\
\hline
\end{tabular}




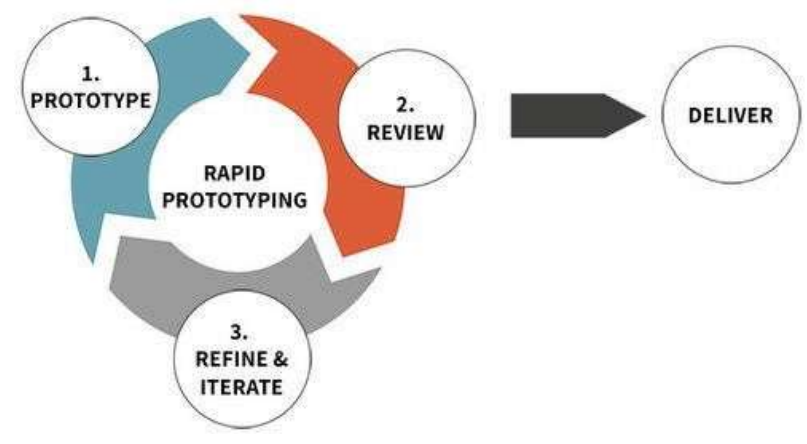

Rajah 3. Model Rapid Prototyping [25]

\subsubsection{Model ADDIE}

Menurut Molenda [26], model ADDIE digunakan untuk menggambarkan pendekatan sistematik terhadap pembangunan pengajaran, yang hampir sama dengan pembangunan sistem pengajaran. Ini bermakna model ADDIE adalah model reka bentuk pengajaran generik yang digunakan untuk membangunkan bahan pengajaran. Ia juga merupakan model yang menyediakan proses yang teratur. Fasa-Fasa yang termasuk adalah Analisis, Reka Bentuk, Pembangunan, Pelaksanaan dan Penilaian (Formatif dan Summatif).

\section{Jadual 6. Kelebihan dan Kekurangan Model ADDIE [26]}

\begin{tabular}{ll}
\hline \multicolumn{1}{c}{ Kelebihan } & \multicolumn{1}{c}{ Kelemahan } \\
\hline $\begin{array}{l}\text { Ia boleh menjadi kos efektif, menjimatkan masa } \\
\text { dan menggalakkan pembelajaran yang berkesan. }\end{array}$ & $\begin{array}{l}\text { Proses yang tipis memerlukan analisis yang tidak } \\
\text { realistik secara terlaksana bertindak dengan sangat } \\
\text { sedikit dan tidak dapat mengakses elemen kritikal. }\end{array}$ \\
$\begin{array}{ll}\text { Memberi panduan berstruktur untuk mereka } \\
\text { bentuk }\end{array}$ & $\begin{array}{l}\text { Tidak menghiraukan beberapa reality politik. } \\
\text { Peluang terlewat, sumber penting tidak disediakan, } \\
\text { sokongan kurang, dan sasaran peralihan. }\end{array}$ \\
\hline $\begin{array}{l}\text { Boleh diubah dengan mudah untuk menyesuaikan } \\
\text { mana-mana modul pembelajaran }\end{array}$ & $\begin{array}{l}\text { Papan cerita adalah alat yang tidak berkesan untuk } \\
\text { membuat, berkomunikasi dan menilai alternatif reka } \\
\text { bentuk. Reka bentuk yang kurang bagus tidak } \\
\text { diiktiraf sehingga terlambat. }\end{array}$ \\
\hline $\begin{array}{l}\text { Membolehkan untuk menilai keperluan pelajar; } \\
\text { dan penilaian keberkesanan program latihan } \\
\text { menggunakan proses dengan hasil yang boleh } \\
\text { diukur yang khusus. }\end{array}$ & $\begin{array}{l}\text { Tiada cara untuk menangani kesalahan atau idea } \\
\text { yang baik melalui proses ini. }\end{array}$ \\
\hline
\end{tabular}

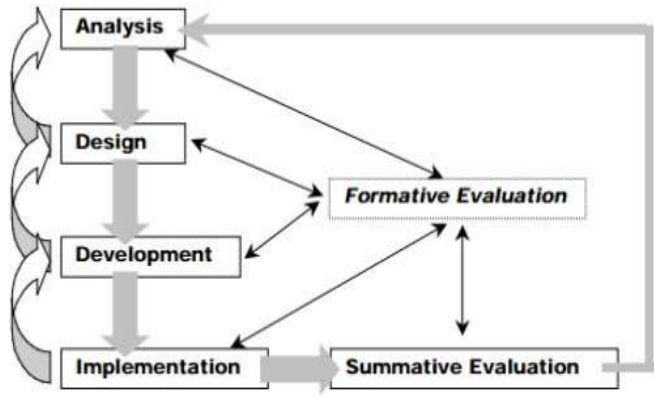

Rajah 4. Model ADDIE 


\subsubsection{Model ASSURE}

Model ASSURE adalah sistem pengajaran atau garis panduan yang guru boleh gunakan untuk membangunkan rancangan pelajaran yang mengintegrasikan penggunaan teknologi dan media [27]. Model ASSURE memberi tumpuan kepada pelajar dan keseluruhan hasil untuk mencapai matlamat pembelajaran. Model ASSURE adalah evolusi model umum ADDIE. Walaupun model ASSURE mempunyai enam langkah, yang tidak betul-betul sesuai dengan lima ADDIE, ASSURE juga membentangkan fasa reka bentuk, dan berkongsi dengannya dua ciri utama: fokus awal pada analisis dan struktur klik [28] [29].

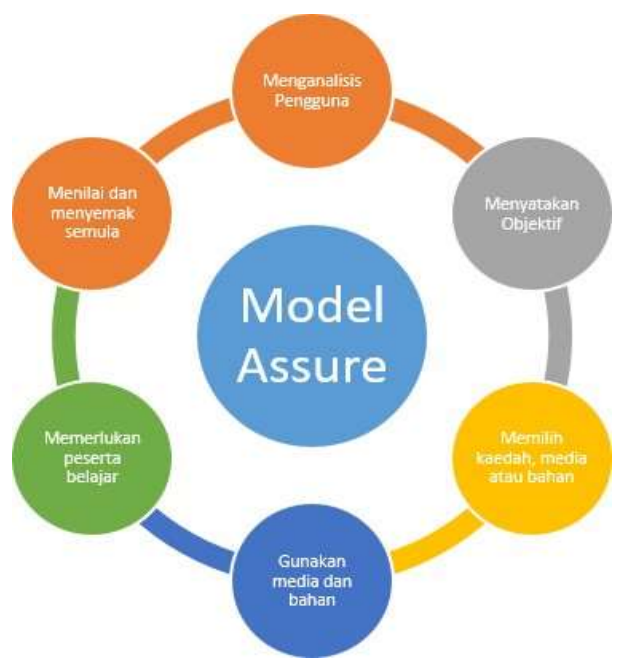

Rajah 5. Model ASSURE

Jadual 7. Kelebihan dan Kekurangan Model ASSURE [28]

\begin{tabular}{ll}
\hline \multicolumn{1}{c}{ Kelebihan } & \multicolumn{1}{c}{ Kelemahan } \\
\hline $\begin{array}{l}\text { Ia boleh menjadi kos efektif, } \\
\text { menjimatkan masa dan menggalakkan } \\
\text { pembelajaran yang berkesan. }\end{array}$ & $\begin{array}{l}\text { Proses yang tipis memerlukan analisis yang } \\
\text { tidak realistik secara terlaksana bertindak } \\
\text { dengan sangat sedikit dan tidak dapat } \\
\text { mengakses elemen kritikal. }\end{array}$ \\
\hline $\begin{array}{l}\text { Memberi panduan berstruktur untuk } \\
\text { mereka bentuk }\end{array}$ & $\begin{array}{l}\text { Tidak menghiraukan beberapa reality } \\
\text { politik. Peluang terlewat, sumber penting } \\
\text { tidak disediakan, sokongan kurang, dan }\end{array}$ \\
& sasaran peralihan. \\
\hline $\begin{array}{l}\text { Boleh diubah dengan mudah untuk } \\
\text { menyesuaikan mana-mana modul }\end{array}$ & $\begin{array}{l}\text { Papan cerita adalah alat yang tidak berkesan } \\
\text { pembelajaran }\end{array}$ \\
$\begin{array}{l}\text { untuk membuat, berkomunikasi dan menilai } \\
\text { alternatif reka bentuk. Reka bentuk yang }\end{array}$ \\
kurang bagus tidak diiktiraf sehingga \\
terlambat.
\end{tabular}


Perspektif utamanya ialah bagaimana menyatukan media (apa saja media) ke dalam instruksi dalam satu kaedah yang mampu menghasilkan hasil belajar yang diinginkan. Dibangunkan oleh Robert Heinich dan Michael Molenda beberapa dekad lalu, model ASSURE mendapat populariti kerana penggunaannya dalam buku teks popular untuk para pendidik. Ia adalah panduan reka bentuk pengajaran yang terkenal yang menggunakan perspektif konstruktivis, yang menggabungkan multimedia dan teknologi untuk meningkatkan persekitaran pembelajaran [30]. Model ASSURE diubahsuai untuk digunakan oleh guru di dalam kelas oleh Smaldino, Lowther \& Russell, 2008. [28].

Guru lebih suka model ASSURE kerana ia direka untuk digunakan selama beberapa jam pengajaran dan untuk setiap pelajar. Model ini tidak memerlukan kerumitan media yang tinggi, pengetahuan id yang mendalam, atau semakan semula reka bentuk yang tinggi [31]. Perbezaan utama antara guru yang tidak berpengalaman dan guru pakar ialah guru pakar dengan mudah boleh menentukan kandungan, strategi pengajaran yang sesuai, dan medium penghantaran. Model ASSURE memberi guru baru (tidak berpengalaman) peta jalan umum untuk mengikuti pelajar untuk berfikir lebih seperti pakar guru [28].

\section{Metodologi Kajian}

\subsection{ADDIE Model}

Metodologi yang digunakan untuk kajian penyelidikan ini ialah model ADDIE. Rajah 6 meringkaskan model ini yang terdiri daripada lima fasa yang memerlukan perolehan keperluan analisis, reka bentuk, pembangunan koswer, implementasi dan penilaian. Hal ini bertujuan untuk merancang pembangunan pembelajaran dengan sistematik bagi mencapai objektif utama kajian penyelidikan bersesuaian dengan masa, kos dan tempat.

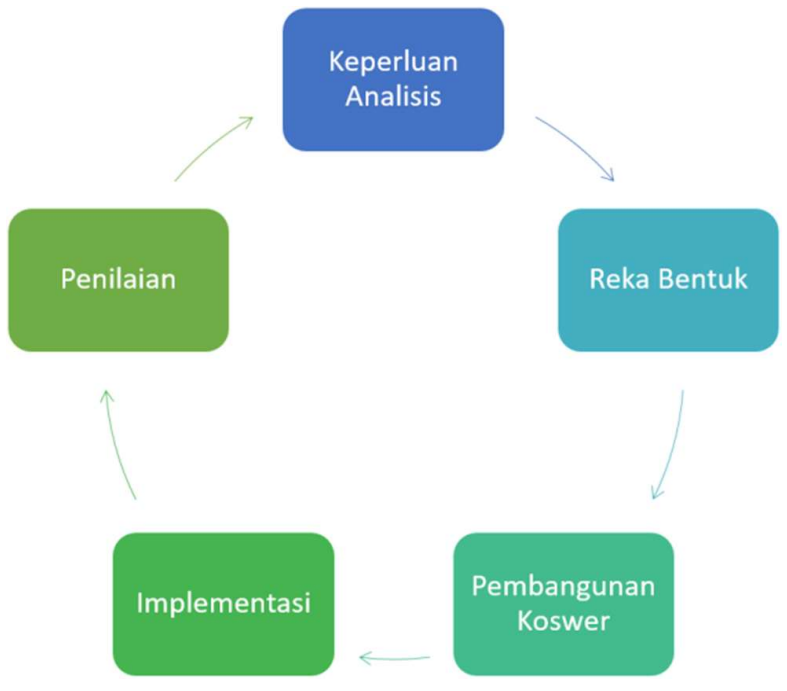

Rajah 6. Fasa Dalam Model ADDIE [32]

Pemilihan model ADDIE adalah dipengaruhi pencapaian objektif dan limitasi kajian penyelidikan ini. Selain itu, pemilihan model ini juga adalah rangka kerja generik, sistematik dan dilaksanakan secara langkah demi langkah. Model ini dapat memastikan pembangunan koswer secara berstruktur dan penilaian kebolehgunaan koswer ICDC berdasarkan maklum balas responden.

Selain itu, model ADDIE juga dapat memastikan pencapaian objektif kajian penyelidikan melalui analisis keperluan reka bentuk dan pembangunan bahan-bahan pembelajaran. Justeru, model ADDIE adalah bersesuaian kerana model ADDIE membuat penilaian setiap fasa atau antara fasa dapat dilakukan sebelum berpindah untuk melaksanakan versi akhir jika mengetahui sebarang kesilapan fasa.

Dalam pembangunan koswer ICDC ini, terdapat beberapa paparan antara muka yang telah dibina. Rajah 7 dan Rajah 8 menunjukkan paparan antaramuka koswer ICDC yang telah dibangunkan. Kesemua elemen multimedia dimasukkan ke dalam koswer meliputi kombinasi atau gabungan teks, audio, animasi, grafik dan interaktiviti. 


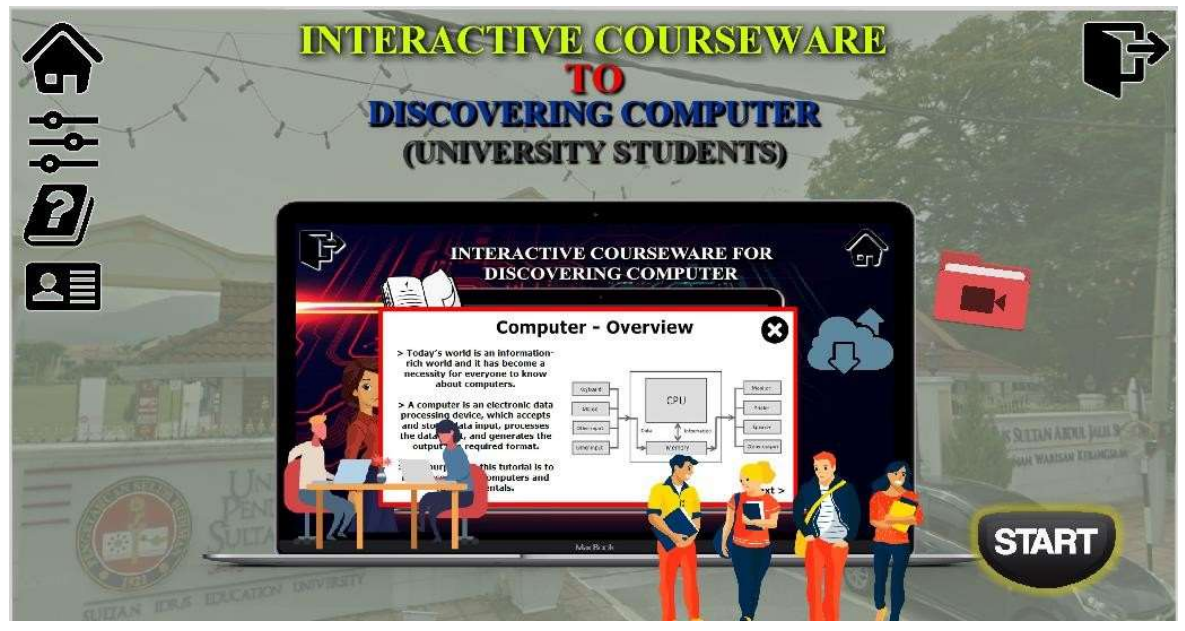

Rajah 7. Paparan Utama Koswer ICDC

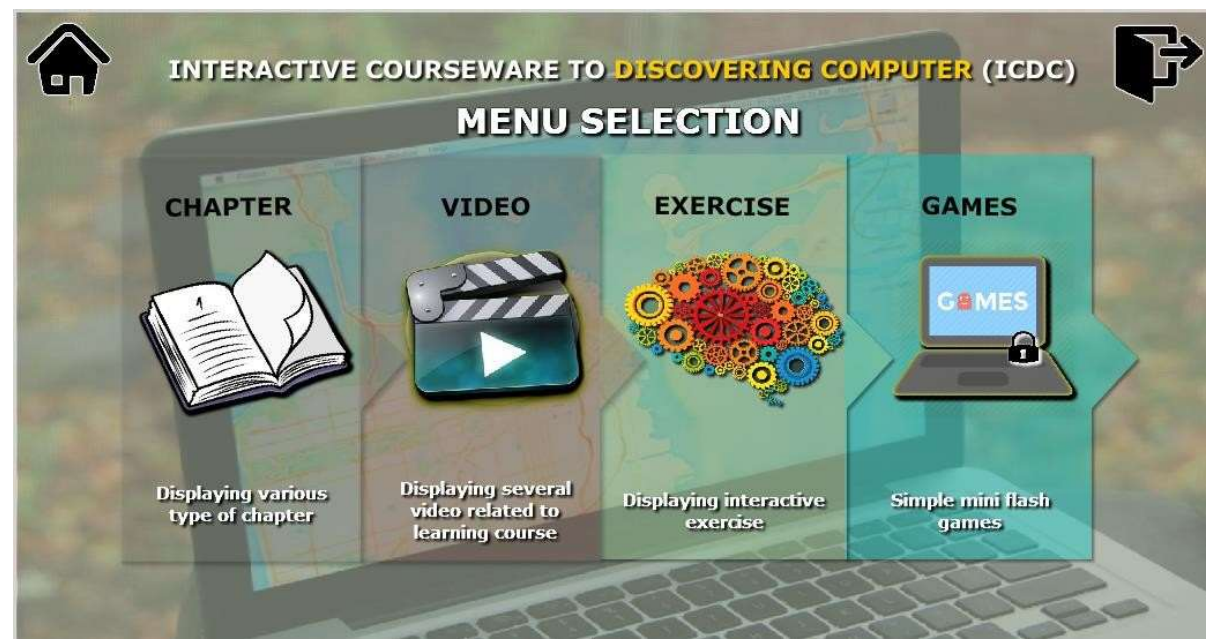

Rajah 8. Paparan Menu Selection Koswer ICDC

\subsection{Reka Bentuk Kajian}

Kajian ini dijalankan menggunakan borang soal selidik di mana kaedah pengumpulan data adalah secara kuantitatif. Kaedah ini digunakan untuk mencari jawapan kepada persoalan kajian kerana ia dapat mengukur subjek kajian berdasarkan soal selidik kepuasan pengguna yang disediakan serta sesuai dengan saiz populasi yang dinyatakan.

\subsection{Populasi dan Sampel Kajian}

Kajian ini dijalankan di UPSI, Tanjong Malim, Perak yang melibatkan pemilihan responden seramai 33 orang daripada beberapa kursus di UPSI serta dikhususkan kepada beberapa kursus sahaja antaranya iaitu kursus Kejuruteraan Koswer (Koswer Pendidikan), Kursus Pendidikan Teknologi Maklumat, Kursus Pendidikan Biologi, Kursus Pendidikan Multimedia, Kursus Pengiklanan, Kursus Pendidikan Matematik dan Kursus yang tera- khir iaitu Kursus Pendidikan Awal Kanak-Kanak (Rujuk Lampiran E). Umumnya, lokasi yang dipilih ini bersesuaian dengan populasi dan tujuan kajian ini dijalankan dan penggunaannya dapat menjawab kesemua persoalan kajian. Selain itu, faktor kos, masa dan kemampuan pengkaji juga memberi kesan dalam pemilihan lokasi kajian. Prosedur pensampelan yang dipilih adalah pensampelan rawak. 


\subsection{Intrumen Kajian}

Bagi mencapai objektif yang telah dinyatakan sebelum ini, instrumen yang digunakan ialah borang soal selidik. Selain itu, penggunaan data sekunder turut diaplikasi dengan membuat rujukan melalui sumber rangkaian (internet). Kajian penyelidikan yang dijalankan ini adalah berbentuk deskriptif atau dikenali juga sebagai kuantitatif yang menggunakan instumen borang soal selidik. Data kuantitatif dikumpulkan hasil daripada soal selidik tersebut. Satu set borang soal selidik telah disediakan menggunakan Google Forms untuk mendapatkan maklumat tentang elemen kebolehfungsian. Responden diminta memberikan maklumat dengan menandakan pada ruang yang berkenaan atau mengisi pada ruang kosong yang disediakan. Tujuannya supaya responden yang dipilih dapat menjawab item-item yang diajukan berdasarkan kepada pengalaman semasa menguji aplikasi ini.

\section{Dapatan Kajian dan Analisis Kebolehfungsian}

Rajah 9 merupakan keputusan terhadap kebolehfungsian terhadap produk yang dibangunkan.

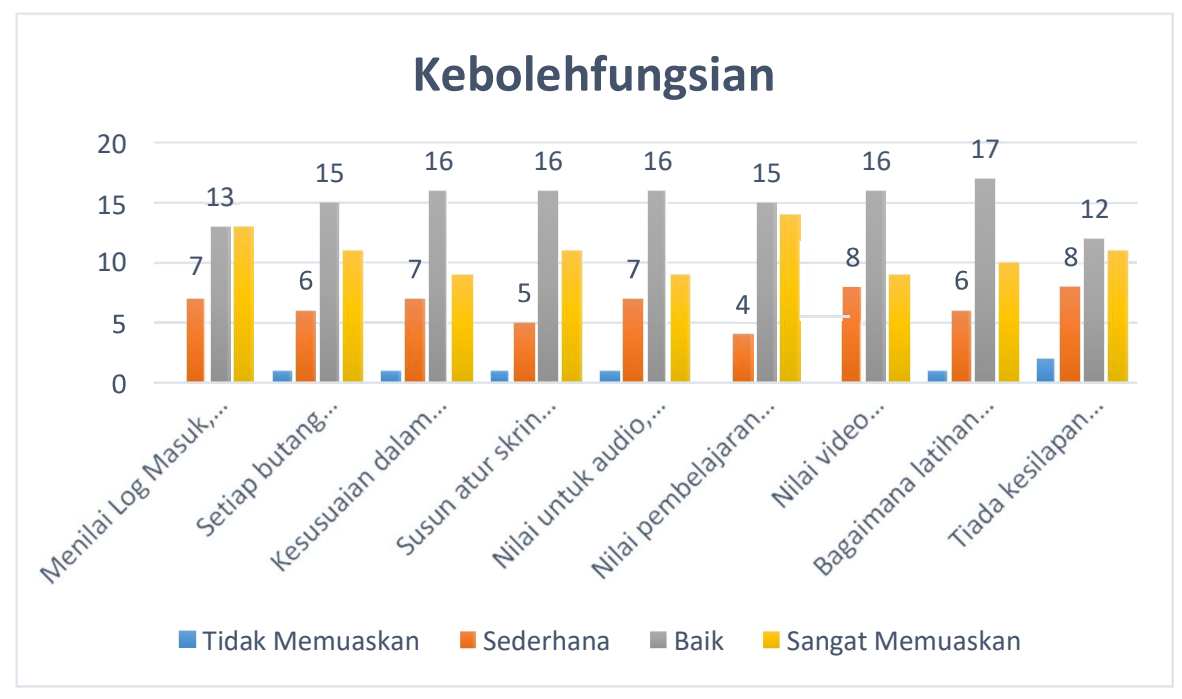

Rajah 9. Kebolehfungsian

Berdasarkan keputusan penilaian log masuk, daftar akaun dan tambah profil, seramai 13 (39\%) orang responden masing-masing memilih 'Sangat Memuaskan' dan 'Baik' sahaja dengan kebolehfungsian untuk log masuk, daftar akaun dan tambah profil. Manakala, seramai 7 (21\%) orang peserta menilai 'Sederhana untuk kebolehfungsian ini. Berdasarkan keputusan penilaian yang dibuat bagi setiap butang bernavigasi, seramai 11(33\%) orang responden memilih 'Sangat Memuaskan' dengan kebolehfungsian pada butang. Manakala, seramai 15 (46\%) orang responden menilai 'Baik' sahaja serta seramai $6(18 \%)$ orang peserta menilai 'Sederhana' untuk setiap butang ini bernavigasi serta seorang (3\%) sahaja yang menilai 'Tidak Memuaskan'. Berdasarkan penilaian yang dibuat berdasarkan kesesuaian dalam menggunakan butang, seramai $9(27 \%)$ orang responden sangat berpuas hati dengan kesesuaian butang di dalam koswer ini. Manakala, seramai $16(49 \%)$ orang peserta menilai baik. Seterusnya, seramai 6 $(18 \%)$ orang responden menilai sederhana dalam kesesuaian butang serta seorang $(3 \%)$ menilai tidak memuaskan.

Berdasarkan keputusan penilaian susun atur skrin mudah dinavigasi, seramai 11 (33\%) orang responden memilih 'Sangat Memuaskan' dengan susun atur skrin. Manakala, seramai 16 (49\%) orang responden menilai 'Baik' sahaja serta seramai $5(15 \%)$ orang peserta menilai sederhana untuk susun atur skrin mudah bernavigasi serta seorang (3\%) sahaja yang menilai 'Tidak Memuaskan'. Berdasarkan penilaian bagi audio, video dan animasi, seramai $9(27 \%)$ orang responden menilai 'Sangat Memuaskan' dengan audio, video dan animasi dalam koswer ini. Manakala, seramai 16 (49\%) orang peserta menilai 'Baik'. Seterusnya, seramai 7 (21\%) orang responden menilai 'Sederhana', namun seorang (3\%) menilai 'Tidak Memuaskan'. Berdasarkan penilaian dibuat terhadap modul pembelajaran, seramai 14 (42\%) orang responden menilai 'Sangat Memuaskan'. Manakala, seramai $15(45 \%)$ orang responden menilai 
'Baik' sahaja serta empat (12\%) orang responden menilai 'Sederhana'.

Berdasarkan penilaian terhadap video pembelajaran, adakah berfungsi dengan betul atau tidak, seramai $9(27 \%)$ orang responden menilai 'Sangat Memuaskan' dengan video pembelajaran dalam koswer ini. Manakala, majoriti seramai 16 (49\%) orang peserta menilai 'Baik'. Seterusnya, seramai 8 (24\%) orang responden menilai 'Sederhana' untuk video pembelajaran. Berdasarkan penilaian terhadap bagaimana kuiz berfungsi, seramai 10 (30\%) orang responden memilih 'Sangat Memuaskan' dengan kebolehfungsian kuiz pembelajaran. Manakala, majoriti seramai 17 (52\%) orang responden menilai 'Baik' sahaja serta 6 (18\%) orang responden menilai 'Sederhana' dan seorang (3\%) sahaja menilai 'Tidak Memuaskan'. Berdasarkan penilaian terhadap kesilapan atau ralat, seramai 11 (33\%) orang responden menilai 'Sangat Memuaskan' dengan tidak ada kesilapan dan bebas ralat pada produk ini. Manakala, majoriti seramai $12(36 \%)$ orang responden menilai 'Baik' sahaja serta $8(24 \%)$ orang responden menilai 'Sederhana' dan dua (6\%) sahaja menilai 'Tidak Memuaskan' untuk kesilapan terhadap produk ini.

Dapatan kajian menunjukkan setiap kriteria yang diuji mendapati koswer ICDC ini mencapai dan berada pada tahap yang baik dan bebas ralat meliputi kebolehfungsian dan juga antaramuka koswer. Justeru, dapat disimpulkan daripada analisis yang diperolehi bahawa koswer ICDC ini merupakan idea yang bagus untuk meningkatkan pengetahuan dan tahap kefahaman pelajar serta menggalakkan pengguna koswer yang berasakan web ini sebagai BBM bagi pembelajaran kendiri. Dengan itu, secara tidak langsung, pembangunan koswer ICDC ini telah mencapai objektif kajian. Bab 6 merumuskan secara keseluruhan kajian penyelidikan serta mengutarakan cadangan lanjutan bagi tujuan penambahbaikan koswer.

\section{Kesimpulan}

Koswer ICDC ini telah berjaya dibangunkan selepas melalui beberapa fasa iaitu fasa analisis di mana pengumpulan keseluruhan maklumat dilakukan. Seterusnya, fasa reka bentuk antaramuka di mana antaramuka diterjemahkan ke dalam bentuk papan cerita. Fasa pembangunan melibatkan transformasi papan cerita ke dalam bentuk koswer sebenar. Fasa implementasi melibatkan pelaksanaan koswer di mana koswer tersedia untuk digunakan. Fasa pengujian melibatkan seramai 30 orang pelajar UPSI sebagai sample bagi menguji kebolehgunaan, kebolehfungsian, antaramuka dan isi kandungan koswer ICDC ini. Secara keseluruhannya, koswer ICDC ini telah membantu menyelesaikan masalah yang berlaku pada koswer sedia ada.

Objektif Pertama pada kajian ini bertujuan untuk mendapatkan pemahaman yang lebih baik tentang sifat koswer multimedia interaktif bagi proses PnP diperingkat universiti melibatkan pemahaman unsurunsur asas komputer dan beberapa komponen komputer. Di samping meminimumkan aspek animasi dan penggunaan warna di dalam koswer ICDC. Koswer ICDC ini dibangunkan berdasarkan permasalahan yang berlaku di dalam koswer sedia ada. Oleh kerana kajian ini telah selesai dibina dan dilaksanakan, maka didapati bahawa objektif kajian dapat dicapai. Semua fasa yang terlibat adalah keperluan untuk mencapai matlamat kajian.

Objektif yang kedua pada kajian ini ialah untuk membangunkan koswer ICDC bagi tajuk Discovering Computer bagi pelajar UPSI untuk mengaksesnya secara percuma. Hal ini akan menimbulkan rasa suka untuk belajar dan untuk membolehkan pelajar menggunakannya sebagai BBM. Terdapat beberapa aktiviti yang telah dilakukan untuk mencapai objektif kedua iaitu aktiviti pengumpulan maklumat, menganalisis keperluan dan dokumen keperluan dilakukan. Semua aktiviti dilakukan dengan melakukan penilaian serta pemerhatian dengan mengedarkan borang kaji selidik. Dapatan menunjukan bahawa, kebanyakan pengguna tidak menggemari gemar dengan koswer sedia ada kerana memerlukan pengguna untuk membayar ataupun menyuruh pengguna untuk melanggan (Subscribe) laman koswer dan membawa mereka ke halaman pembayaran. Hal ini membuat pengguna berasa sukar dan menyusahkan para pengguna untuk belajar dan mengakses bahan di internet. Justeru, koswer ICDC ini dapat mencapai objektif iaitu mem- bangunkan koswer multimedia interaktif berasaskan web bagi topik berkaitan komputer iaitu Discovering Computer yang dapat dicapai secara percuma.

Objektif ketiga bagi kajian ini adalah menyesuaikan bahan pendidikan kepada teknologi terkini. Alat pembelajaran yang sedia ada tidak mengikuti perkembangan teknologi terkini dan kebanyakkannya hanya dibangunkan untuk kanak-kanak. Walaupun tenaga kerja pendidikan sudah lama, namun ia tidak meningkatkan kualiti teknologi seperti sekarang. Jadi, bagi koswer yang telah dibangunkan dapat mencapai objektifnya bagi menganalisis ciri-ciri keperluan koswer melalui analisis dokumen dan pemerhatian. 
Objektif keempat ialah untuk membuat penilaian terhadap antaramuka pengguna, kebolehfungsian, kebolehcapaian dan juga isi kandungan koswer ICDC yang telah dibangunkan. Melalui dapatan yang diperolehi hasil dari analisis item soal selidik prestasi terhadap keempat-empat kategori penilaian ini telah mencapai objektif secara keseluruhannya di mana, koswer yang sudah siap dibina ditunjukkan kepada pengguna untuk dinilai kebolehgunaannya.

Pengetahuan dan isi kandungan dalam koswer ini lebih mudah dan menarik untuk dibaca berbanding menggunakan buku yang tebal. Sasaran utama koswer koswer komputer ialah pelajar universiti antara 18 tahun hingga 25 tahun. Proses pembelajaran sangat penting untuk pelajar kerana dengan interaktiviti, persekitaran pembelajaran dan unsur-unsur yang digunakan dalam koswer dapat menjana pengetahuan pembelajaran pelajar. Akhir sekali, melalui analisis yang diperlukan terhadap aktiviti-aktiviti pembelajaran, koswer yang memuaskan telah dihasilkan. Di akhir pembelajaran koswer multimedia interaktif, pelajar mempunyai pengetahuan yang bermanfaat seperti tahu menggunakan komputer dan mencari maklumat dengan menggunakan web. Sehubungan dengan itu, pengetahuan yang diberikan adalah sangat berguna kepada untuk pelajar. Ia boleh menarik pelajar untuk mempelajari pembelajaran dengan gaya tersendiri dan tidak lagi perlu untuk membeli buku tambahan sebagai rujukan.

Kekurangan utama koswer ICDC yang dibangunkan ini adalah tidak memfokuskan sepenuhnya kepada koswer berasaskan web kerana pembangun pada awalnya lebih memfokuskan terhadap pembangunan koswer sahaja. Kesannya, terdapat sedikit kekurangan pada koswer ICDC yang dibangunkan, namun tidaklah begitu ketara sekiranya diberikan penambahbaikan masa bagi koswer ICDC. Batasan kajian ini adalah versi XAMPP sebagai pelayan adalah tidak stabil kerana kemaskinian baru phpMyadmin adalah tidak serasi dengan versi yang lain. Koswer ICDC ini juga turut mempunyai limitasi rangkaian (sumber internet).

\section{Rujukan}

[1] S. Alessi, "Designing Educational Support in System-Dynamics BasedInteractive Learning Environments," Sage Journals, June 2000

[2] Tablatin, C. L. S. Patacsil, F. F. Cenas and V. Paulo, "Design and devel opment of an information technology fundamentals multimedia koswer for dynamic learning environment," Journal of Advances in Technology and Engineering Research, pp. 202-210, 2017

[3] Patacsil, F. Frederick, and C. L. S. Tablatin. "Exploring the importance of soft and hard skills as perceived by IT internship students and industry: A gap analysis," Journal of Technology and Science Education, vol. 7, no. 3, pp. 347-368, 2017.

[4] Pacol, A. Caren, Patacsil, and Frederick, "Drill and Practice Koswer in IT Fundamentals," [Online] Available: https://www. mendeley.com/catalogue/drill-practice-koswer-it-funda mentals/. [Acessed: 2018]

[5] J. D. Mayer, P. Salovey, D. R. Caruso, and G. Sitarenios, "Emotional intelligence as a standard intelligence," Emotion, vol. 1, vo. 3, pp. 232-242, 2001. doi:10.1037/1528-3542.1.3.232

[6] Shishodia, Shishir, G. Sethi, and B. B. Aggarwal. "Curcumin: getting back to the roots," Annals of the New York Academy of sciences, vol. 1056, no. 1, pp. 206-217, 2005.

[7] Vaughan, Sebastian, I. J. Coward, R. C. Bast, A. Berchuck, J. S. Berek, J. D. Brenton, G. Coukos "Rethinking ovarian cancer: recommendations for improving outcomes," Nature Reviews Cancer, vol. 11, no. 10. pp. 719-725, 2011.

[8] A. M. Elmagzoub, "For effective use of multimedia in education, teachers must develop their own educational multimedia applications," Turkish Online Journal of Educational Technology, vol. 62-68, 2015.

[9] Haryono, I. Rika, M. Kawilarang, and N. A. Prastowo. "Leg length discrepancy in college students and its association with low back pain: a preliminary study." Journal of Anthropology of Sport and Physical Education, vol. 3, no. 2, pp. 15-18, 2019.

[10] Sofiani, E. Galuh, and S. Rahmawaty, "Tingkat pengetahuan gizi, asupan energi-protein dan status gizi pasien kanker nasofaring yang mendapatkan kemoterapi." Darussalam nutrition journal vol. 2, no. 2, pp. 14-20, 2018.

[11] R. I. Safayi, L. Karimi, N. Shomoossi, T. M. Ahmadi, "The Relationship Between Spiritual WellBeing and Mental Health of University Students," Journal Of Sabzevar University Of Medical Sciences Winter 2011, vol. 17, no. 4, pp. 274-280, 2011.

[12] Low, J. Liang, M. L. Wu, D. B. Aziz, B. Laleu, and T. Dick. "Screening of TB actives for activity against nontuberculous mycobacteria delivers high hit rates," Frontiers in microbiology, vol. 8, 
pp. 15-39, 2017.

[13] Sadaf, Ayesha, Newby, Timothy, Ertmer, and Peggy, "An Investigation of The Factors That Influence Preservice Teachers Intentions and Integration of Web 2.0 Tools," Educational Technology Research and Development, 2015. doi: 64.10.1007/s1 1423-015-9410-9.

[14] Khalil, K. Mohammed, and A. I. Elkhider, "Applying learning theories and instructional design models for effective instruction," Advances in Physiology Education, vol. 40, no. 2, pp. 56-147, 2016.

[15] Mayer, E. Richard, "Incorporating motivation into multimedia learning," Learning and instruction, vol. 29, pp. 171-173, 2014.

[16] Andriyanto, R. Darmawan, and J. O. Haryanto, Analisis pengaruh internet marketing terhadap pembentukan word of mouth dan brand awareness untuk memunculkan intention to buy. Jawa Tengah: Universitas Kristen Satya Wacana, 2010.

[17] Pilli, Olga, and M. Aksu, "The effects of computer-assisted instruction on the achievement, attitudes and retention of fourth grade mathematics students in North Cyprus," Computers \& Education, vol. 62, pp. 62-71, 2013.

[18] Paul, S. Shyam, M. D. Sitangshu, B. S. Punia, K. S. Das, G. Singh, M. N. Ashar, and R. Kumar. "Effect of Feeding Isolates of Anaerobic Fungus Neocallimastix Sp. CF 17 On Growth Rate and Fibre Digestion in Buffalo Calves," Archives of animal nutrition, vol. 65, no. 3, pp. 215-228, 2011.

[19] H. M. Musfiqon, Pengembangan media dan sumber pembelajaran. Jakarta: PT. Prestasi Pustakaraya (2012).

[20] R. Crafword, "Health As A Meaningful Social Practice," An Interdisciplinary Journal for the Social Study of Health, Illnes and Medicine, vol. 10, no. 4, pp. 401-420, 2006.

[21] Saeed, Seham, F. Islahudin, M. M. Bakry, and A. M. Redzuan, "The Practice of Complementary and Alternative Medicine Among Chronic Kidney Disease Patients," Journal of Advanced Pharmacy Education \& Research, vol. 8, no. 3, pp. 31, 2018.

[22] A. S. Blanco, Development of Hybrid Mobile Apps. Singapore: University of Applied Science, 2014.

[23] Bonetti, Paola, M. Testoni, M. Scandurra, M. Ponzoni, R. Piva, A. A. Mensah, A. Rinaldi, "Deregulation of ETS1 and FLI1 Contributes To the Pathogenesis of Diffuse Large B-cell lymphoma," Blood, The Journal of the American Society of Hematology, vol. 122, no. 13, pp. 2233-2241, 2013.

[24] R. Archee, Is Blended Learning Making Us Stupid, Too?," Open Journal of Social Sciences, vol, 3, no. 9, 2015.

[25] Hande, Gurler, F. Arzu, G. Nilgun, A. S. Serhat, C. Alper, K. Ece, A. Serhat, and F. Murat, "Investigation On The Etiology Of Subclinical Mastitis In Jersey And Hybrid Jersey Dairy Cows," Acta Veterinaria, vol. 65, no. 3, 2015.

[26] Molenda, J. K. Swierczek, and W. Zajac, "Functional materials for the IT-SOFC," Journal of Power Sources, vol. 173, no. 2, pp. 657-670, 2007.

[27] Smaldino, E. Sharon, L. L. Deborah, J. D. Russell, and C. Mims, Instructional technology and media for learning. London: Pearson, 2008.

[28] Laurensius, Nurdi, and S. N. Triani, "Pemajasan dalam Kumpulan Cerpen Rectoverso Karya Dewi Lestari," Jurnal Pendidikan Bahasa dan Sastra Indonesia, vol. 2, no. 1, pp. 18-25, 2017.

[29] Heinich, R. M. Molenda, and J. D. Russell, "Visual design," Instructional media and the new technologies of instruction, 1993.

[30] H. Lefebvre, A Critical Intruduction. England: Routledge, 2006

[31] Baharom, Ahmad and M. Universiti, "Effects of Two Growing Systems on Growth and Yield Performance of Three Musk Melon (Cucumis melo L. reticulatus), Varieties Under Controlled Environment Structure, 2007

[32] Dick and Walter, "The Dick and Carey model: Will it survive the decade?," Educational technology research and development, vol. 44, no. 3, pp. 55-63, 1996. 